\title{
ADN bacteriano en pacientes con cirrosis y ascitis estéril. Papel como marcador de translocación bacteriana y herramienta pronóstica
}

\author{
J. M. González-Navajas ${ }^{1,3}$, R. Francés ${ }^{2,3}$ y J. Such ${ }^{2,3}$ \\ ${ }^{1}$ School of Medicine. University of California. San Diego, EE.UU. ${ }^{2}$ Unidad de Hepatología. Hospital General \\ Universitario. Alicante, España. ${ }^{3}$ CIBERehd. Instituto de Salud Carlos III. Madrid, España
}

\begin{abstract}
RESUMEN
Durante la última década hemos presenciado un aumento de la cantidad de datos relativos a la presencia de translocación bacteriana en los modelos experimentales de cirrosis. Sin embargo, los estudios clínicos se han visto limitados por la falta de métodos no invasivos para estudiar dicho fenómeno. En los últimos años, las investigaciones realizadas en nuestro laboratorio se han centrado en la detección del ADN bacteriano en el suero y el líquido ascítico de los pacientes con cirrosis y ascitis estéril, y en las implicaciones clínicas que ello conlleva. Al principio, gracias a un método basado en la reacción en cadena de la polimerasa (PCR) y el secuenciamiento automatizado de nucleótidos, pudimos detectar e identificar la presencia de fragmentos de ADN bacteriano en dichos pacientes con ascitis no neutrocítica y con cultivo negativo. Desde entonces hemos acumulado una serie de datos que indican que la presencia de ADN bacteriano podría desempeñar un papel importante no sólo como marcador de translocación bacteriana, sino también como factor pronóstico a corto plazo. Expondremos aquí el pasado, el presente y el futuro de esta línea de investigación.
\end{abstract}

Palabras clave: Translocación bacteriana. Cirrosis. ADN bacteriano. Ascitis estéril.

\begin{abstract}
During the last decade, we have witnessed an increase in the amount of data related with the presence of bacterial translocation in experimental models of cirrhosis. However, clinical studies have been limited by the lack of non-invasive methods to study this phenomenon. Over the past years, the research developed in our laboratory has been focused on the detection of bacterial DNA in serum and ascitic fluid of patients with cirrhosis and sterile ascites, the clinical and immunological implications of such finding. Initially, by means of a polymerase chain reaction (PCR)-based method and automated nucleotide sequencing, we were able to detect and identify the presence of fragments of bacterial DNA in the mentioned patients with culture-negative, non-neutrocytic ascites. Since then, we have accumulated a core of data suggesting that the presence of bacterial DNA may have an important role not only as a marker of bacterial translocation, but also as a shortterm prognostic factor. Here, we discuss the past, present and future of this line of investigation.
\end{abstract}

Key words: Bacterial translocation. Cirrhosis. Bacterial DNA. Sterile ascites.

González-Navajas JM, Francés R, Such J. ADN bacteriano en pacientes con cirrosis y ascitis estéril. Papel como marcador de translocación bacteriana y herramienta pronóstica. Rev Esp Enferm Dig 2007; 99: 599-603.

\section{INTRODUCCIÓN}

La translocación bacteriana (TB) es un proceso por el cual las bacterias de la luz del intestino migran a través

Recibido: 20-09-07.

Aceptado: 26-09-07.

Correspondencia: José Such. Unidad de Hepatología. Hospital General Universitario. Avda. Pintor Baeza, 12. 03010 Alicante. e-mail: such_jos@gva.es de la barrera intestinal hacia los ganglios linfáticos mesentéricos y otros sitios extraintestinales (1). Esta alteración de la flora digestiva y el consiguiente movimiento de microorganismos fuera de su entorno natural se acepta generalmente que es el principal suceso del desarrollo de infecciones bacterianas en los pacientes cirróticos. Entre estas infecciones causadas por la TB, la peritonitis bacteriana espontánea (PBE) es probablemente la complicación más importante y peligrosa para la vida (2). 
Se han propuesto varios mecanismos para explicar la TB en la cirrosis, como el sobrecrecimiento bacteriano intestinal, el aumento de la permeabilidad del intestino y las alteraciones de las defensas inmunitarias del huésped (3-5). De hecho, se han observado sobrecrecimientos de bacterias gramnegativas en el tubo digestivo tanto en modelos experimentales de cirrosis como en pacientes cirróticos $(6,7)$. Una vez alcanzado cierto umbral crítico en la luz intestinal, las bacterias podrían ser capaces de escapar de la misma y translocarse hacia los ganglios linfáticos mesentéricos, la sangre y, finalmente, el líquido ascítico (LA). Además, si la capacidad bactericida del líquido ascítico sobre estos invasores está comprometida, como ocurre en los pacientes con cirrosis avanzada, puede producirse un crecimiento bacteriano incontrolado y desarrollarse una PBE (8).

Los estudios clínicos de la TB se han visto limitados tradicionalmente por la falta de métodos no invasivos para detectar su presencia. Durante los últimos años, las investigaciones realizadas en nuestro laboratorio se han centrado en la importancia que tiene la presencia simultánea de ADN bacteriano en el suero y el LA de los pacientes con cirrosis avanzada y ascitis neutrocítica y de cultivo negativo, así como en su posible papel como marcador secundario de TB. En este artículo revisaremos los últimos hallazgos que indican que la presencia de ADN bacteriano en el LA de estos pacientes desempeña un papel principal.

\section{PRESENCIA DE ADN BACTERIANO EN LOS PACIENTES CON ASCITIS ESTÉRIL}

Como la mayoría de los episodios de siembra bacteriana en pacientes con cirrosis no puede detectarse por los métodos tradicionales del hemocultivo o el cultivo de LA (9), nosotros desarrollamos un método más sensible, basado en la reacción en cadena de la polimerasa (PCR), para detectar estos acontecimientos. Por medio de una gran amplificación del ARN ribosómico de 16S, al principio detectamos la presencia simultánea de ADN bacteriano en el suero y el LA del 30-40\% de los pacientes con ascitis estéril (10). El secuenciamiento de los nucleótidos de los fragmentos amplificados permitió identificar que $E$. coli era el principal origen del ADN bacteriano de nuestra serie $(77 \%)$. Además, la similitud de nucleótidos entre los fragmentos detectados en el suero y el LA de cada paciente era, en la mayoría de los casos, superior al $99,7 \%$. Estos datos suponían la primera detección de restos bacterianos en los pacientes con cultivo negativo de LA y apuntaban hacia un único episodio de translocación como origen de las bacterias identificadas. Sin embargo, como se explica a continuación, experimentos posteriores señalaron la existencia de episodios repetidos de TB en una proporción importante de pacientes.

Las evaluaciones siguientes mostraron que los macrófagos peritoneales de los pacientes con presencia de
ADN bacteriano habían sido imprimados para producir cantidades mayores de óxido nítrico (NO) y citocinas proinflamatorias (11), como mostraban los niveles aumentados de factor de necrosis tumoral (TNF) $\alpha$, interferón (IFN) $\gamma$ e interleucina (IL) 12. Esta situación de preactivación es muy parecida a la descrita en los pacientes antes de la aparición de un episodio de PBS nosocomial (12), y con toda probabilidad es atribuible al efecto inmunoestimulante de los motivos CpG sin metilar que existen en el ADN bacteriano. Curiosamente, al ser estimulados por lipopolisacáridos (LPS), los macrófagos de los pacientes sin presencia de ADN bacteriano mostraban un aumento significativo de los niveles de TNF- $\alpha$ e IL- 6 , pero dicho aumento no se observaba en los macrófagos ya activados de los pacientes con ADN bacteriano, lo que indica que la reserva funcional de estas células estaba disminuida (13).

\section{SIGNOS DE LOS EPISODIOS REPETIDOS DE TB}

Como se explicó anteriormente, la mayoría de los datos que existen en la bibliografía señalan varios mecanismos para explicar la TB, como el sobrecrecimiento de bacterias en el intestino. Sin embargo, se sabe poco de la cinética de estos sucesos. Así, una de las preguntas clave es si las bacterias se translocan por algún suceso único o si, por el contrario, estos microorganismos cruzan constantemente la pared intestinal. Para explorar esta cuestión llevamos a cabo un estudio secuencial de la presencia de ADN bacteriano en la sangre de pacientes con cirrosis y ascitis. En esta investigación, el patrón temporal de la eliminación del ADN bacteriano se evaluó en muestras de suero obtenidas cada 8 horas durante un periodo de 3 días (14). Inesperadamente, se hallaron dos patrones diferentes de eliminación del ADN bacteriano al cuantificarlo. En el $42 \%$ de los casos, el ADN bacteriano se eliminaba casi totalmente de la sangre en un periodo de tiempo breve (16 horas), mientras que en el 58\% restante, la cantidad de ADN bacteriano circulante variaba con el tiempo, incluidas la completa desaparición y reaparición de dichos fragmentos (14). Estos resultados, junto con el hecho de que todas las muestras positivas de un mismo paciente mostraban una similitud superior al $99,5 \%$ en la secuencia de nucleótidos, señalaban decididamente la existencia de episodios repetidos de TB por el mismo microorganismo.

\section{ADN BACTERIANO COMO MARCADOR DE TB}

La mayoría de los datos que avalan una mayor TB en la cirrosis proceden de estudios realizados con animales de experimentación en los que la TB se definió como la presencia de cultivos positivos para al menos una espe- 
cie de la flora intestinal en ganglios linfáticos mesentéricos (GLM) extirpados quirúrgicamente (15). Estos estudios mostraron que la prevalencia de la TB desde la luz digestiva hacia los GLM es de alrededor del $40 \%$ en los modelos de cirrosis en ratas, y de alrededor del $80 \%$ en los animales con PBS $(16,17)$. Según esto, si la presencia de ADN bacteriano en el suero o el LA se debe realmente a episodios de TB, deberíamos ser capaces de detectar dicho ADN bacteriano al mismo tiempo en estos líquidos biológicos y en los GLM. Para confirmar esta hipótesis desarrollamos un estudio en el modelo $\mathrm{CCl} 4$ de cirrosis en ratas en el que la presencia de ADN bacteriano se comprobó en GLM con cultivo positivo o GLM con cultivo negativo y en distintos líquidos biológicos (LA, suero y líquido pleural) (18). Como era de esperar, el ADN de una determinada especie de bacteria detectado en los líquidos biológicos estaba presente en los GLM en el $100 \%$ de los casos, aunque el que la bacteria fuera viable en los GLM, es decir, cumpliera con los criterios clásicos de la TB, sólo ocurría en el 63,6\% de los mismos. Curiosamente, la presencia de ADN bacteriano en los GLM se asoció también a una marcada respuesta inflamatoria indicada por una mayor producción de TNF $\alpha$, IL-6 y NOx, y que era parecida en las muestras con cultivo positivo y negativo. Estos datos, junto con el hecho de que el ADN bacteriano no se detectó en los animales sometidos a contaminación intestinal con norfloxacino, avalaron nuestra hipótesis inicial de que la presencia de ADN bacteriano en el LA de los pacientes con cirrosis avanzada podría constituir un marcador diagnóstico de la TB, por lo que señalamos que los criterios de la TB podrían ampliarse para incluir la presencia de fragmentos bacterianos en los GLM incluso en los casos con cultivo negativo.

La proteína transportadora de lipopolisacáridos (LBP), una proteína de fase aguda de tipo I capaz de unirse tanto al CD14 de membrana como al CD14 soluble, es otra molécula que se ha propuesto como marcador de TB en los últimos años. En un estudio reciente, los niveles de LBP se regularon al alza en un subconjunto de pacientes con marcado deterioro inmunitario y hemodinámico (19). Después, la administración de norfloxacino mejoró estas alteraciones, lo que indica la participación de bacterias gramnegativas en el proceso. Sin embargo, en pacientes con cirrosis también se ha observado un mayor número de episodios bacterianos por microorganismos grampositivos, la mayoría en pacientes ingresados sometidos a intervenciones invasivas $(20,21)$. Como la LBP está regulada principalmente por los LPS, ausentes en las bacterias grampositivas, la medición de esta proteína podría subestimar la importancia de estos episodios de translocación de grampositivos. De hecho, en un estudio reciente llevado a cabo en nuestro laboratorio, hemos hallado que la respuesta inflamatoria no es distinta en los pacientes con presencia de ADN bacteriano procedente de microorganismos gramnegativos o grampositivos (22).

\section{IMPORTANCIA CLIINICA DE LA PRESENCIA DE ADN BACTERIANO EN EL SUERO Y EL LÍQUIDO ASCÍTICO}

Hasta ahora, los datos que hemos expuesto indican fehacientemente la identificación de un nuevo subgrupo de pacientes con cirrosis e indicios de fragmentos de genoma bacteriano en suero y LA. Estos hallazgos, no obstante, no se asociaron ni a signos ni a síntomas específicos de la enfermedad (10). Por otra parte, es bien sabido que el ADN bacteriano contiene secuencias inmunoestimuladoras caracterizadas por un alto contenido de motivos no metilados de citidina-fosfato-guanosina $(\mathrm{CpG})$, que son prevalentes en el ADN del genoma de las bacterias pero no de los mamíferos $(23,24)$. Estos motivos CpG son reconocidos de forma específica por un miembro de la familia de los receptores de tipo peaje (TLR), el TLR-9. La activación del TLR-9 provoca una serie anterógrada de sucesos señalizadores que afectan a muchas vías, incluida la de factor nuclear kappa B (NF- $\kappa \mathrm{B})$, y finalmente conduce a la activación de los genes diana y a la producción de citocinas y quimiocinas proinflamatorias (23-26). De hecho, este conjunto de datos aporta la lógica que permite explicar nuestra observación de que los episodios bacterianos asintomáticos habían en realidad imprimado a los macrófagos de los pacientes cirróticos para producir cantidades elevadas de citocinas proinflamatorias y $\mathrm{NOx}$ $(11,13)$.

Para seguir evaluando la hipótesis de que la presencia de ADN bacteriano en el suero y el LA de los pacientes cirróticos supone un estímulo lo bastante grande como para poner en marcha toda la red de citocinas proinflamatorias, recientemente realizamos un estudio de los mediadores solubles implicados en los procesos fagocíticos e inflamatorios, es decir, las citocinas y el sistema del complemento, en cuatro conjuntos distintos de pacientes con presencia/ausencia de ADN bacteriano, un episodio activo de PBS o la descontaminación intestinal selectiva (DIS) previa con norfloxacino. En este estudio demostramos que el perfil citocínico proinflamatorio de las células T colaboradoras 1 (Th1) (medido por los niveles de TNF$\alpha$, IFN- $\gamma$ e IL-12) en los pacientes con presencia de ADN bacteriano en suero y LA es muy similar al detectado en los pacientes con PBS, y mayor que el de los enfermos sin tales fragmentos genómicos y que el de los sometidos a DIS con norfloxacino. Además, los niveles de estas citocinas Th1 en los pacientes sin indicios de ADN bacteriano eran indistinguibles de los detectados en los enfermos sometidos a DIS. La misma tendencia se observó cuando analizamos las proteínas activadoras del sistema del complemento, con idéntica activación de la vía alternativa en los pacientes con presencia de ADN bacteriano y en los que tenían PBS (Frances R, González-Navajas JM, Zapater P, Muñoz C, Caño R, Pascual S, et al. Bacterial DNA induces the complement system activation in serum and ascitis fluid from patients with advanced cirrhosis. J Clin Immunol 2007; 27 (4): 438-44). En conjun- 
to, estos datos indican con solidez que el ADN bacteriano desencadena una respuesta inmunitaria proinflamatoria dependiente de células $\mathrm{T}$ en los pacientes con cirrosis, $\mathrm{y}$ avala la idea de un subgrupo de pacientes no tratados y con perfil proinflamatorio que podrían tener consecuencias clínicas y complicaciones graves, en relación o no con la PBS.

Esto nos lleva a la última investigación desarrollada por nuestro grupo, en la que realizamos un estudio multicéntrico prospectivo para analizar el significado pronóstico de la presencia de ADN bacteriano en el suero y el LA de 141 pacientes con cirrosis y ascitis estéril, ya publicado en forma de abstract (27). En este estudio hallamos una tasa de mortalidad significativamente mayor entre los pacientes con presencia de ADN bacteriano durante un periodo de tres meses después del ingreso en el estudio. Curiosamente, seis de las siete muertes ocurridas entre los enfermos con ADN bacteriano positivo se produjeron en los diecisiete días posteriores a la detección de fragmentos del ARNr de $16 \mathrm{~S}$ en estos pacientes, mientras que no hubo muertes entre los pacientes sin tales fragmentos. Además, los niveles de NOx en suero y LA fueron significativamente mayores en estos pacientes con presencia de ADN bacteriano.

Lo más importante es que, cuando analizamos la supervivencia según la presencia de ADN bacteriano, los pacientes presentaban supervivencias similares con independencia de la edad y los niveles de NOx, y que la única relación significativa se estableció entre la presencia o ausencia de ADN bacteriano y la muerte. En este sentido ya habíamos indicado que la presencia de ADN bacteriano en el suero y el LA de los pacientes con cirrosis y ascitis estéril podía identificar a un subgrupo de pacientes con un marcado perfil proinflamatorio capaz de provocar graves complicaciones clínicas (se expuso anteriormente). Ahora, estos datos de supervivecia suponen la prueba necesaria para confirmar aquella hipótesis, y que la presencia de ADN bacteriano constituye un factor independiente que predice la mortalidad en el corto plazo.

El hecho de que el ADN bacteriano se haya también asociado a un aumento del NOx macrofágico (11), un vasodilatador bien conocido, nos lleva a proponer un mecanismo por el que la presencia de ADN bacteriano en un paciente aumenta la síntesis local de NOx, deteriorando así una situación hemodinámica ya inestable, facilitando la aparición de más episodios de TB y conduciendo finalmente a la aparición de diferentes complicaciones clínicas, no necesariamente relacionadas con la PBS, y a una mortalidad mayor.

\section{RESUMEN Y PERSPECTIVAS DE FUTURO}

En los últimos años ha habido un considerable avance en nuestros conocimientos del papel que desempeña el ADN bacteriano en la regulación de las respuestas inmunitarias de los pacientes con cirrosis y ascitis no neutrocí- tica y con cultivo negativo. Como se ha expuesto en esta revisión, hemos descrito en primer lugar la presencia de ADN bacteriano en alrededor del 35\% de los pacientes con las características mencionadas, junto con una marcada preactivación de los mediadores proinflamatorios y el NOx por los macrófagos peritoneales. En segundo lugar, hemos probado en un modelo animal de cirrosis que el ADN bacteriano está siempre al mismo tiempo en los GLM y los distintos líquidos biológicos, lo que indica que la detección de estos fragmentos bacterianos realmente se asocia a los episodios de TB. Tercero, la cinética de la eliminación del ADN bacteriano mostró que tales fragmentos son capaces de alcanzar el LA en al menos dos patrones secuenciales distintos, lo que indica la existencia de episodios repetidos de TB. Y finalmente aportamos pruebas de que la presencia de ADN bacteriano en sangre y LA se relaciona con una mayor tasa de mortalidad y constituye un factor independiente capaz de predecir la supervivencia en el corto plazo.

Como la detección del ADN bacteriano y la presencia de otras afecciones clínicas, como una mayor permeabilidad o el sobrecrecimiento de bacterias intestinales, no son tenidas en cuenta por los sistemas pronósticos habituales, como las escalas de Child-Pugh o MELD, seguir explorando el valor diagnóstico o el papel causal del ADN bacteriano podría aportarnos una potente herramienta al considerar los tratamientos. Si suponemos, como sugieren claramente los datos que hemos expuesto, que la presencia de ADN bacteriano indica un deterioro del paciente acompañado de respuesta inflamatoria y de la liberación de mediadores solubles como el NOx que finalmente afectan a la supervivencia, podría pensarse en realizar un ensayo clínico sobre la profilaxis primaria en pacientes con $\mathrm{ADN}$ bacteriano.

\section{BIBLIOGRAFÍA}

1. Berg RD, Garlington AW. Translocation of certain indigenous bacteria from the gastrointestinal tract to the mesenteric lymph nodes and other organs in a gnotobiotic mouse model. Infect Immun 1979; 23: 403-11.

2. Such J, Runyon BA. Spontaneous bacterial peritonitis. Clin Infect Dis 1998; 27: 669-74; quiz 675-66.

3. Campillo B, Pernet P, Bories PN, Richardet JP, Devanlay M, Aussel C. Intestinal permeability in liver cirrhosis: Relationship with severe septic complications. Eur J Gastroenterol Hepatol 1999; 11: 755-9.

4. Guarner C, Soriano G. Spontaneous bacterial peritonitis. Semin Liver Dis 1997; 17: 203-17.

5. Pascual S, Such J, Esteban A, Zapater P, Casellas JA, Aparicio JR, et al. Intestinal permeability is increased in patients with advanced cirrhosis. Hepatogastroenterology 2003; 50: 1482-6.

6. Chang CS, Chen GH, Lien HC, Yeh HZ. Small intestine dysmotility and bacterial overgrowth in cirrhotic patients with spontaneous bacterial peritonitis. Hepatology 1998; 28: 1187-90.

7. Guarner C, Runyon BA, Young S, Heck M, Sheikh MY. Intestinal bacterial overgrowth and bacterial translocation in cirrhotic rats with ascites. J Hepatol 1997; 26: 1372-8.

8. Runyon BA. Early events in spontaneous bacterial peritonitis. Gut 2004; 53: 782-4.

9. Runyon BA, Canawati HN, Akriviadis EA. Optimization of ascitic fluid culture technique. Gastroenterology 1988; 95: 1351-5. 
10. Such J, Francés R, Muñoz C, Zapater P, Casellas JA, Cifuentes A, et al. Detection and identification of bacterial DNA in patients with cirrhosis and culture-negative, nonneutrocytic ascites. Hepatology 2002; 36: 135-41.

11. Francés R, Muñoz C, Zapater P, Uceda F, Gascon I, Pascual S, et al. Bacterial DNA activates cell mediated immune response and nitric oxide overproduction in peritoneal macrophages from patients with cirrhosis and ascites. Gut 2004; 53: 860-4.

12. Such J, Hillebrand DJ, Guarner C, Berk L, Zapater P, Westengard J, et al. Tumor necrosis factor-alpha, interleukin-6, nitric oxide in sterile ascitic fluid and serum from patients with cirrhosis who subsequently develop ascitic fluid infection. Dig Dis Sci 2001; 46: 2360-6.

13. Francés R, Rodríguez E, Muñoz C, Zapater P, De la ML, Ndongo $\mathrm{M}$, et al. Intracellular cytokine expression in peritoneal monocyte/macrophages obtained from patients with cirrhosis and presence of bacterial DNA. Eur J Gastroenterol Hepatol 2005; 17: 4551 .

14. Francés R, Benlloch S, Zapater P, González JM, Lozano B, Muñoz $\mathrm{C}$, et al. A sequential study of serum bacterial DNA in patients with advanced cirrhosis and ascites. Hepatology 2004; 39: 484-91.

15. Wiest R, García-Tsao G. Bacterial translocation (BT) in cirrhosis. Hepatology 2005; 41: 422-33.

16. García-Tsao G, Lee FY, Barden GE, Cartun R, West AB. Bacterial translocation to mesenteric lymph nodes is increased in cirrhotic rats with ascites. Gastroenterology 1995; 108: 1835-41.

17. Runyon BA, Borzio M, Young S, Squier SU, Guarner C, Runyon MA. Effect of selective bowel decontamination with norfloxacin on spontaneous bacterial peritonitis, translocation, survival in an animal model of cirrhosis. Hepatology 1995; 21: 1719-24.

18. Guarner C, González-Navajas JM, Sánchez E, Soriando G, Francés $\mathrm{R}$, Chiva $\mathrm{M}$, et al. The detection of bacterial DNA in blood of rats with CCl4-induced cirrhosis with ascites represents episodes of bacterial translocation. Hepatology 2006; 44: 633-9.

19. Albillos A, de la Hera A, González M, Moya JL, Calleja JL, Monserrat $\mathrm{J}$, et al. Increased lipopolysaccharide binding protein in cirrhotic patients with marked immune and hemodynamic derangement. Hepatology 2003; 37: 208-17.

20. Cirera I, Bauer TM, Navasa M, Vila J, Grande L, Taura P, et al. Bacterial translocation of enteric organisms in patients with cirrhosis. J Hepatol 2001; 34: 32-7.

21. Fernandez J, Navasa M, Gómez J, Colmenero J, Vila J, Arroyo V, et al. Bacterial infections in cirrhosis: epidemiological changes with invasive procedures and norfloxacin prophylaxis. Hepatology 2002; 35: $140-8$.

22. Such J, Zapater P, González-Navajas JM, Muñoz C, Benlloch S, Pascual S, et al. La Presencia de ADN bacteriano en sangre se asocia a niveles elevados de LBP en pacientes con cirrosis y ascitis. Gastroenterol Hepatol 2005; 28 (Supl. 1): 80-1.

23. Hemmi H, Takeuchi O, Kawai T, Kaisho T, Sato S, Sanjo H, et al. A Toll-like receptor recognizes bacterial DNA. Nature 2000; 408: 7405 .

24. Krieg AM. CpG motifs: the active ingredient in bacterial extracts? Nat Med 2003; 9: 831-5.

25. Akira S, Takeda K, Kaisho T. Toll-like receptors: Critical proteins linking innate and acquired immunity. Nat Immunol 2001; 2: 675-80.

26. Krieg AM. CpG motifs in bacterial DNA and their immune effects. Annu Rev Immunol 2002; 20: 709-60.

27. Zapater P, Francés R, González-Navajas JM, de la Hoz M, Moreu R, Pascual S, et al. La presencia de ADN bacteriano es un predictor pronóstico a corto plazo en pacientes cirróticos con ascitis. Resultados de un estudio multicéntrico nacional. Gastroenterol Hepatol 2006; 29 (Supl. 1): 117. 